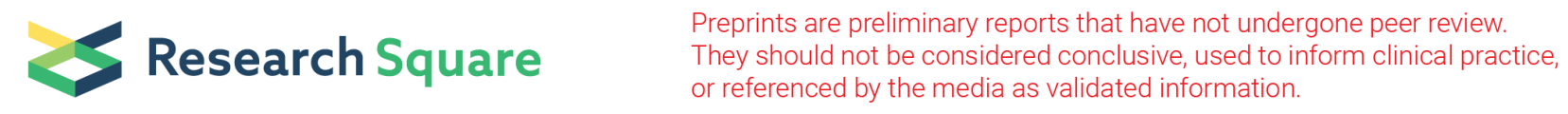

\title{
Introducing an Efficient Socio-Economically Oriented Data Envelopment Analysis Method for Selecting the Optimum Groundwater Dam Site Location
}

\author{
Soroush Maghsoudy \\ University of Tehran \\ Nader Fathianpour ( $\sim$ fathian@iut.ac.ir) \\ Isfahan University of Technology
}

\section{Research Article}

Keywords: Groundwater management, Data envelopment, Potential improvement, Input/output contribution, Long term efficiency.

Posted Date: August 20th, 2021

DOI: https://doi.org/10.21203/rs.3.rs-610931/v1

License: (c) (i) This work is licensed under a Creative Commons Attribution 4.0 International License. Read Full License 


\section{Abstract}

Groundwater dams are commonly constructed in arid and semiarid regions for subsurface storage of water. In this study, an attempt is made to present a new efficiency-based site selection methodology for constructing groundwater dams based on socio-economic approaches. The site selection process was conducted in a semiarid region in Central Iran. A total of 13 different criteria in four major classes of climate, geology, hydrology, and socio-economy were defined. Nine multi-criteria decision making (MCDM) methods were used for site selection, followed by integrating the results by Borda and Copeland algorithms. The data envelopment analysis (DEA) was employed for selecting the optimum groundwater dam site from the same choices. The DEA method is based on efficiency and it is capable for evaluating the performance of each alternative. Four different scenarios, including the CCR-Input, CCR-Output, BCC-Input, BCC-Output, were used to implement the DEA approach. In addition, the socio-economic-based optimization equation was solved by considering three socio-economic criteria as the output of the DEA model. The results show that the CCR method provides the best results for groundwater dam site selection by maximizing the outputs. Two algorithms, namely the Potential Improvement and Input/output contribution, were used to evaluate the performance of each alternative. These algorithms show the amount of improvement for each selected option. The application of the DEA method, as a new approach for groundwater dam site selection, can increase the performance of the selected option and facilitate dam maintenance throughout its operation time.

\section{Introduction}

The scarcity of drinking water in arid to semi-arid regions has drawn attention to developing efficient methods of retaining groundwater resources (Ertsen 2009). Constructing groundwater dams is among the methods that have been used for a long time since ancient Greek, Persia, and parts of Africa (Nilson 1988). There have been various studies on groundwater dams; for instance, geophysical studies by lkard (2014) or rock mechanics studies of geotechnical parameters in such structures by Taufiq (2010). Other similar research works include those conducted by Suk (2012) and Chang (2019).

Groundwater dams are constructed by state organizations mostly in regions with decreasing populations, trying to prevent migration. Regional site selection studies for the groundwater dam construction has been an interesting research topic. For example, Jamali, in 2013, 2014, and 2018, conducted extensive studies on the use of Geographical Information Systems (GIS) and multi criteria decision making methods in groundwater dam site selection at watershed basin scales (Jamali 2013, Jamali 2014, and Jamali 2018). Dortaj et al. (2020a and b) investigated fuzzy and non-fuzzy multivariate decisionmaking methods for dam site selection.

Groundwater dams need to be investigated from different significant perspectives that some factors remain effective even after dam construction. For instance, Adham (2011) investigated the effect of climate change on a groundwater dam performance in Japan; or, Ishida (2003, 2006) and Lima (2020) studied the effect of groundwater dams on the environment and the quality of water after construction.

Furthermore, other important factors affecting groundwater dams include the role of socio-economic issues and local-native communities near the site of construction (Lasage, 2008, Ersten, 2009). Such challenges have made the groundwater dam site selection a complicated problem and multifaceted, both in technical and socio-economic aspects.

The data envelopment analysis (DEA) method, which is a comprehensive approach for calculating the efficiency, can be helpful for such purposes. Farrell (1957) is one of the pioneers in this field in economic science. Charnes et al. (1978) modified the Farrell model and called it data envelopment analysis. In recent years, DEA has expanded from economy to other science and engineering fields, such as environment and geoscience studies. Wang and Chen (2014) presented an approach named DEA environmental assessment in the context of environmental issues. Mohebali et al. (2020) used the DEA approach as a tool to assess the effect of industrial factories on the environment from a sustainable development perspective. Lozano et al. (2009) applied data envelopment analysis for life circle assessment (LCA) of the organizations and industries and also the efficient production of agricultural products (Mohammadi 2011, Mousavi-Aval 2012).

In the present study, the DEA method was used for groundwater dam site selection to an efficiency-based engineering issue. In addition, this approach can determine the ideal form of different alternatives. It can also control the effective factors on each alternative throughout the dam's operation time to maintain the efficiency of the dam with a socio-economic perspective. Some practical tools in DEA method like potential improvement (PI) and input/output contribution were conducted to pay careful attention to various aspects of native-local communities and the economic development released by the construction of groundwater dam.

\section{Theoretical Background}

\section{2-1-Subsurface Dams and Applications}

Subsurface dams are usually built in arid and semiarid regions with lack of water supplies (Nilson 1988). Figure 1 shows different parts of these dams and the effective components on their construction. As seen, they are generally built across the catchment outlets (Hanson 1986).. A slope of 0 to 4 degrees, highly permeable upstream alluvium beds, lack of faults for water seepage, dry and warm climates, seasonal rivers, the presence of villages and agricultural lands near the dam are the factors that affect its construction. Local and native communities have a crucial role in the construction and maintenance of these kinds of structures. Site selection through finding the appropriate alternative is an important task that is managed by state organizations 
Multi-criteria decision-making methods (MCDM) are among the robust tools for solving site selection problems in engineering projects (Rahman 2012 and Adham 2016). The most common MCDM methods used for this purpose include AHP, TOPSIS, ELECTRE, and PROMETHEE (Rahman 2016, Adham 2011). The theoretical principles of these methods can be found in various references (Tzeng2011). Figure 2 shows the MCDM methods used in the current study. Also, the combination of Borda and Copeland algorithms were used to find a unique solution, as discussed in detail by Mohebali et al. (2019).

\section{2-3- Data Envelopment Analysis as a New Tools}

\section{2-3-1- DEA Concepts and a Simple Example}

Data Envelopment Analysis (DEA) is a technique used for calculating the efficiency of industrial units. Efficiency means the ratio of output to input in an industrial unit, which also means that the unit can yield a higher amount of produced materials (output) by consuming fewer raw materials (input) (Farell 1957). Figure 3 presents a schematic and straightforward 2D illustration of the DEA concept. The DEA method is implemented by fitting an efficiency front on data. This efficiency front is recognized by two names, CCR Front and BCC Front (Fig. 3), named after their inventors (Charns1978). In DEA problems, the data that are located on these fronts are efficient, and their efficiency number is equal to one. The other data can get a lower efficiency value as they are located farther from these fronts.

The DEA method is conducted using four main approaches: CCR-Input oriented, CCR-Output oriented, BCC-Input oriented, and BCC-Output oriented. Figure 4 is designed to show the difference between these four DEA approaches (Cooper, 2006). This example has four DMUs, including A, B, C, and D. Each of these DMUs have one input and one output. The efficiency fronts have been illustrated using the BCC and CCR methods. In the CCR method, the efficiency of the $\mathrm{DMU}_{\mathrm{B}}$ is 1 , and in the $\mathrm{BCC}$ approach, the $\mathrm{DMU}_{\mathrm{A}}, \mathrm{DMU}_{\mathrm{B}}$, and $\mathrm{DMU}_{\mathrm{C}}$ are efficient with an efficiency score of 1 . In order to determine the difference between input-oriented and output-oriented approaches, the efficiency of unit " $D$ " was analyzed.

Table 2 shows the efficiency values of unit $D$ for different DEA methods. To reach the efficiency front, point $D$ should move along the input axis toward the left to touchpoints $\mathrm{R}$ or $\mathrm{Q}$. This distance shows the deviation of point $\mathrm{D}$ from maximum efficiency. In the output-oriented state, however, point $\mathrm{D}$ should move along the output axis to reach the efficiency front. Reaching point $\mathrm{S}$ is equal to BCC-Output-oriented, and reaching point W is equal to CCR-Output oriented. Table 2 shows the exact calculated values for the efficiency of unit D in different DEA methods.

\section{2-3-2- Different DEA Algorithms and Optimization Models}

When the number of inputs and outputs of each unit (DMU) exceeds one, the DEA method cannot be solved geometrically and illustrate a graphical diagram, as Figs. 3 and 4 . The problem, however, should be transformed into an efficiency problem. This linear programming problem can be solved by defining some mathematical efficiency models and solving them using operational research methods such as simplex. This method aims to find the input and output coefficients, $u_{r}$ and $v_{i}$. By finding these coefficients, the efficiency of each DMU is calculated. The optimization functions of four main approaches of DEA, are presented in Table 2.

In these four DEA models, the score of efficiency for inefficient units are considered between $\mathbf{0}$ and $\mathbf{1}$. Sometimes the score of all units is the same, and the units cannot be ranked. Andersen and Petersen (1993) suggested that the limitation of $\mathrm{j}=\mathrm{k}$ for unit $\mathrm{DMU}_{\mathrm{k}}$ should not be applied. With this modification, the efficient units can have an efficiency score of more than 1. This method is called supper efficiency (Wu, 2012).

\section{Materials And Methods}

\section{3-1-Study Area}

The study area for implementing the DEA algorithm for site selection of groundwater dams is the Isfahan province of Iran (Fig. 5).

In recent years, the employment in the arid and semiarid central parts have been decreased and the migration rate to the cities have affected the agriculture sector (Rahmani 2016). This issue contradicts the goals of sustainable development in the agriculture sector and necessitates planning for the maintenance of the population in this province (Hedayati 2014, Shafiei, 2017).

Accordingly, the Agricultural Research, Education, and Extension Organization (AREEO) of Isfahan province has decided to construct several groundwater dams in this region (Fig. 5). These dams can promote agriculture in these areas and maintain the population of their villages. The current research aims to solve this problem and determine the most efficient alternative by considering the socio-economic approaches. The real photos of the construction sites of groundwater dams have been presented as well in Fig. 5.

\section{3-2- Criteria and Altematives in SSD Site Selection}

First of all, by investigating the available sources and with the help of the experts, the main effective criteria were determined. These include 13 components in four main categories: Climate, Socio-Economy, Geology, and Hydrology (Fig. 6). All of the experts were in the AREEO and completely known the different aspects of the area and groundwater dam site requirements.

\section{3-3- Survey and Weighting}

Loading [MathJax]/jax/output/CommonHTML/fonts/TeX/fontdata.js 
In the next step, 10 experts familiar with the region were invited to allocate each criterion a number of 1 to 9 , whose result is presented in Table 3 . There are multiple methods to combine the expert opinions (Khaki et al. 2015), among which the Geomean method was used in this study. The highest weight was allocated to "stream depth" and the least value to "stream flow type".

As already stated, the site selection decision matrix was built based on the available information and the expert opinions, as shown in Table 4 . The values of this matrix should be quantified and then used in different MCDM algorithms. The knowledge-based approach was used for this purpose. For example, the regional climate component, which exists in three states of Mediterranean, arid, and semiarid, obtained the values $0.4,06$, and 0.5 in the quantification matrix. For component C8 (i.e., faults and fractures), which is in the form of 0 and 1 , in order to avoid using 0 and disturbing the mathematical calculations, the number 0.1 was replaced. The obtained matrix (Table 5) is the base of further calculations.

\section{Results And Discussion}

\section{4-1- Groundwater Dam Site Selection with MCDM Approach}

Nine different MCDM methods were used for the site selection problem, whose results are presented in Table 6. The programming process for all of these methods was conducted by using the MATLAB package. As Fig. 6 shows, alternative A1 (Tameh) was ranked first in 6 out of 9 methods. Alternative A5 (Hoseinabad) was ranked second in most of these methods. There are some differences between the methods in the ranking of other alternatives, which is one of the challenges of multi-criteria decision-making approach.

\section{4-1-1- Coupling the Results (Hybrid-MCDM)}

The variety of methods, and consequently, the variety of the solutions using different approaches lead to difference in the MCDM results. This has created uncertainty in the use of multi-criteria decision-making methods. For this purpose, in the present study, three algorithms, including Average, Borda, and Copeland, have been used to combine the results of different MCDM methods. These combining methods are described in detail in the research of Mohebali et al. (2019). In order to implement prioritization algorithms, it is necessary to create a table like Table 7 that shows the ranking of the alternatives in different methods. The "Average method" is calculated by averaging the rows of this matrix. According to this method, alternatives A1 and A5 occupy the first and second ranks (Table 7).

The second method is the Borda strategy. This method is a pairwise comparison between the ranks of different options in different MCDM methods. Borda matrix is performed by differencing the number of priority of row alternative from the priority of the column alternative in different MCDM methods. The final score for each alternative is obtained from the summation of the numbers in the row line of that alternative in the Borda matrix (Klamler 2005). Table 8 shows the results of combining different MCDM methods with the Borda strategy.

Copeland method is another simple majority strategy. In the Copeland method, having priority or not having priority is the important point. In the Copeland matrix, if the row alternative has priority to the column alternative, the number 1 is placed in the related element of the matrix. If the row alternative has not the priority to the column alternative, the number -1 putting in the related element. Also, if row alternative and column alternative being equal, number 0 put in the element. The final score for each alternative is obtained from the summation of the numbers in the row line of that alternative (Klamler 2005, Mohebali et al. 2019). Table 9 shows the final results of the Copeland method for combining the solutions of different MCDM methods.

Finally, according to Table 10, the results of these three "Noise Free" methods are compared, and a single solution is presented for Hybrid-MCDM.

\section{4-2- Groundwater Dam Site Selection with DEA Approach}

\section{4-2-1-Simple DEA}

In this step, the same decision matrix formed in Table 5 is used here as well. The ten alternatives that are the groundwater dam options constitute the decision-making units (DMUs), and the 13 criteria presented in Fig. 6 constitute the inputs and outputs of the DEA algorithm.

In the Simple DEA method, as shown in Fig. 7, the three criteria C1, C3, and C9, are considered as inputs. In these three criteria the lowering values is better and thy called negative criteria. The other 10 criteria are considered as the output of the DEA model, and the higher values of them are preferred.

In the present study, the DEA problem has been solved by four methods, including CCR and BCC approaches by Input- and Output-oriented. The results of simple DEA method are presented in Table 11. As can be seen in Table 11, the "CCR Min-Input" and "CCR Max-Output" solutions are equal. In such cases, it is said that the CCR method is the correct DEA approach, and the solutions of the BCC model are not very desirable (Adler 2002). As shown in Table 11, in BCC Min-Input model, many options have the same rating and efficiency score. Therefore, it can be concluded that in a simple DEA approach, the CCR method has the best solutions to the problem of locating groundwater dams.

\section{4-2-2-Socio-Economic DEA}

The main purpose of constructing these kinds of dams is to prevent migration and preserve the population of rural areas. Due to the small scale of these projects, the socio-economic dimension of them is critical. Therefore, the socio-economic DEA method has been used to solve the site selection problem. In this case, according to Fig. 8, three socio-economic criteria affecting the construction of the dam, namely C3, C4, and C5, which include "Distance from villages", "Population of downstream", and "Surface area of benefited agricultural lands", are considered as model outputs. The other 10 components are

Loading [MathJax]/jax/output/CommonHTML/fonts/TeX/fontdata.js 
Since in solving the DEA problem, the inputs must be minimized, and the outputs should be maximized, so the numbers in the decision matrix should be changed. In three components $\mathrm{C} 1, \mathrm{C} 3$, and $\mathrm{C} 9$ that were used as output in the simple DEA method, the lower values are preferred. Now that we want to solve the problem with the socio-economic approach, C3 must be reversed and transferred to the outputs. The other components that were in the output must be reversed and transferred to the input. Afterward, the whole matrix is normalized by dividing it by the sum of each column. Table 12 shows the normalized matrix for socio-economic DEA calculations.

All calculations in four main DEA methods are performed using the "Supper-Efficiency" algorithm. The calculations were performed using MATLAB and Frontiers Analyst software. The results obtained for the socio-economic approach in all four methods are shown in Table 13. The solutions of the two CCR methods are the same and with considering this fact that the dominant approach in this issue is socio-economic and three socio-economic components are in the output of the model, the CCR Max-Output method have been chosen as the best model for solving the groundwater dam site selection problem. Therefore, options A1 and A5 are the first and second alternatives for the construction of a groundwater dam, which are consistent with the solutions of the Hybrid-MCDM method, which is obtained by combining nine methods and was noise-free. On the other hand, the advantage of the DEA method is that it does not need to be weighted by the experts and can only be solved by applying the decision matrix. Also, its programming is much easier than the HybridMCDM method, and there is no need to solve 9 different methods and combining them. Another advantage of DEA is that it can be implemented for millions of options, while except for AHP, other MCDM methods for more than 1000 alternatives have critical computer programing limitations.

As shown in Table 14, the DEA can distinguish efficient alternatives from inefficient ones. As shown in this table, out of 10 alternatives, only five options are efficient. Table 14 also shows the benefit of using the supper efficiency method in solving DEA-assisted locating problems. As shown in standard efficiency mode, the first five options are efficient, and number 100 is assigned to them. The supper efficiency approach caused a distinction between these five options and ranking between them.

\section{4-2-3- Efficiency Analysis}

The most important advantage of the DEA method is that it makes it possible to examine the efficiency of different alternatives. Two of the most important performance studies in the DEA method are Potential Improvement Analysis (PIA) and Input/output Contribution (IOC). In the following, both of these methods are examined in evaluating the efficiency of underground dam construction sites.

\section{4-2-3-1- Potential Improvement}

In potential improvement analysis the coefficients $u$ and $v$ for each option are determined and the alternative projected on the efficiency fronts (BCC and CCR). As a result, in each option, an ideal state will be obtained for each of the components. The distance of each component to that ideal state is calculated by using Eq. 4:

$$
\text { Potential Improvement }=\frac{(\text { Target }- \text { Value }) * 100}{\text { Value }}
$$

\section{4}

The potential improvement values for option A1, which is the first priority for the construction of an underground dam among the 10 alternatives, are presented in Table 15. Negative values of potential improvement indicate that the potential of that component can be decreased. It means that in which percent of the reduction in a component, the alternative is still efficient and is in the ideal state. For example, Table 15 shows that there is a potential improvement that the "rainfall" criteria decreased by $68 \%$, and the alternative A1 will still be in the ideal state. In the case of "Stream Depth" criteria, there is no potential improvement for this option, and the criteria are not far from its ideal state.

Figure 9 shows the potential improvement values for the four options $A 1, A 2, A 3$, and A9. An interesting and convenient point in the construction of groundwater dams is that, as shown in Fig. 9, for option A1 in the "Stream Width" criteria, a 49\% reduction potential is obtained. It means that in option A1, the length of the dam can be reduced by $49 \%$ to reach the ideal and efficient state. Due to the low-cost nature of the groundwater dams, this analysis can play an effective role in the costs reducing and is a useful guide for engineers and project managers for further decisions. In other words, this analysis shows that if the length of the dam is reduced by $49 \%$, option A1 is still the most desirable option among these 10 options.

Another interesting point about the C3, C4, and C5 criteria is that, according to the socio-economic approach, if the population of option A1 decreases by more than $86 \%$ after the operation, this option will no longer be efficient.

\section{4-2-3-2- Input/output Contribution}

Another efficiency analysis that the DEA method presents is input/output contribution (IOC) analysis. In this analysis, by obtaining the values of weights $u$ and $v$ for each of the components of each option, the contribution percentage of a certain criterion in the total performance of an alternative can be determine. Figure 10 shows the results of this analysis for the four options $A 1, A 2, A 3$, and $A 9$. The numbers are normalized as well as rounded. This analysis, which acts as a kind of sensitivity analysis, can determine which criteria played a greater role in the performance of each alternative. For example, for option A1, which is the most desirable option for the construction of a groundwater dam, the components of "stream depth", "population" and "area of benefited agricultural lands" have the greatest impact on the efficiency of this option.

Figure 10 shows the same influential components for the other options, and we see that according to the socio-economic approach in the analysis, the components C3, C4, and C5 had a high contribution for all four options, and they play an effective role in the efficiency of these dams. Such kind of Loading [MathJax]/jax/output/CommonHTML/fonts/TeX/fontdata.js 
analyzes provides the possibility of a more in-depth study in selecting the optimal alternative in the construction of water structures, especially groundwater dams.

\section{Conclusion}

Efficiency based site selection is a new method that can be used to select the optimal location for the construction of groundwater dams. The DEA method has made this assessment possible with a socio-economic approach. In the present study, 10 possible options for construction of groundwater dams in a arid region have been evaluated. Two approaches of simple DEA and socio-economic DEA have been used for site selection. The results are compared with a combination of multi-criteria decision-making methods (Hybrid-MCDM) resulting in consistency among solutions. Due to the combination of the results of 9 different multi-criteria decision-making methods using Borda and Copeland algorithms, the final solution is noise free, and the conformity of the DEA results with them shows DEA's ability to solve site selection problems. Two well-known DEA methods, named CCR and BCC, are used to solve the problem through two approaches of minimizing input and maximizing output. In the present study, the solutions of CCR-Input and CCR-Output models have been the same, which shows that our DEA problem model is not of BCC type, and the CCR approach is the correct approach for the problem-solving. All models are solved in supper efficiency mode to make more distinction between options. Another important point is that in the DEA socio-economic approach, sociological parameters and economic parameters are given to the model as the "output". Their maximization in the output-oriented models show critical attention to these parameters for finding suitable sites for constructing groundwater dams in DEA socio-economic approach respect to suatainable development. Also, using the DEA approach in solving this kind of problem can bring the issue of efficiency into site selection and decision making problems in many geoscience fields. The two approaches of "Potential Improvement" and "Input/output Contribution" can be very effective in this regard and evaluate the selected option in terms of efficiency. These kinds of evaluations in the DEA approach help to pay more attention to the critical parameters of the constructed alternative during the operational time. This is an issue that is not seen in any other traditional site selection method except DEA. Another advantage of the DEA approach in comparison to multi-criteria decision-making methods is that it does not require an expert's weights for the criteria. It is independent of the criteria weight and finds the alternative distance from the efficient option.

Another advantage of the DEA method against Hybrid-MCDM is its simple programing and easy to calculate the associated uncertainties, plus no need for coupling the solutions of different MCDM methods. The point of concern in the DEA approach is that, it is better to have more DMUs than the total number of outputs plus inputs. Also, it should be added that, due to the unknown relationship between inputs and outputs in optimization problems, it is always better to obtain all four DEA methods and compared with each other. In the current research, the CCR-Output method with a socio-economic approach is found to be the optimal method to solve the problem of locating groundwater dams.

\section{Declarations}

\section{Acknowledgments}

The authors are very grateful to the Isfahan Agriculture Ministry Research and Development Division for preparing the data and their contribution. Also, many thanks to the colleagues at the industrial collaboration office at Isfhan university of Technology and Mine Environment and Hydrogeology Research Laboratory (MEHR Lab) of the University of Tehran for their help and support. The authors would also acknowledge Sajjad Mohebali, Dr. Hosein Noferesty, Dr. Hasan Zia, Zabihollah Eskandary, and Behrouz Ghobadipour for their kind help and motivations.

\section{Declaration of Interest Statement}

The authors declare that they have no conflict of interest.

\section{Ethical Approval}

The authors acknowledge that they have complied with all ethical standards.

\section{Consent to Participate}

All of the authors having the consent in participation in current manuscript.

\section{Consent to Publish}

The authors having the consent about the publishing of the current manuscript.

\section{Authors Contributions}

Soroush Maghsoudy: Conceptualization, Methodology, Validation, Formal analysis, Investigation, Resources, Software, Writing - original draft, Visualization, Project administration. Nader Fathianpour: Supervision, Resources, Methodology, Writing - review \& editing, Funding acquisition, Project administration.

\section{Funding}

The authors are very grateful to the Isfahan Agriculture Ministry Research and Development Division for preparing the data and their contribution. 


\section{Competing Interests}

The authors declare that they have no competing interest.

\section{Availability of data and materials}

All of the data have been presented in the manuscript text.

\section{References}

1. Adham, A. K. M., Kobayashi, A., \& Murakami, A. (2011). Effect of climatic change on groundwater quality around the subsurface dam. International Journal of Geomate, 1 (1 SERL 1), 25-32.

2. Adler, N., Friedman, L., \& Sinuany-Stern, Z. (2002). Review of ranking methods in the data envelopment analysis context. European Journal of Operational Research, 140(2), 249-265.

3. Andersen, P., \& Petersen, N. C. (1993). A procedure for ranking efficient units in data envelopment analysis. Management science, 39(10), 1261-1264.

4. Chang, Q., Zheng, T., Zheng, X., Zhang, B., Sun, Q., \& Walther, M. (2019). Effect of subsurface dams on saltwater intrusion and fresh groundwater discharge. Journal of Hydrology, 576, 508-519.

5. Charnes, A., Cooper, W. W., \& Rhodes, E. (1978). Measuring the efficiency of decision making units. European Journal of Operational Research, 2(6), 429-444.

6. Cooper, W. W., Seiford, L. M., \& Tone, K. (2006). Introduction to data envelopment analysis and its uses: with DEA-solver software and references. Springer Science \& Business Media.

7. Dortaj, A., Maghsoudy, S., Ardejani, F. D., \& Eskandari, Z. (2020a). A hybrid multi-criteria decision making method for site selection of subsurface dams in semiarid region of Iran. Groundwater for Sustainable Development, 10, 100284.

8. Dortaj, A., Maghsoudy, S., Ardejani, F. D., \& Eskandari, Z. (2020b). Locating suitable sites for construction of subsurface dams in semiarid region of Iran: using modified ELECTRE III. Sustainable Water Resources Management, 6(1), 7.

9. Ertsen, M., \& Hut, R. (2009). Two waterfalls do not hear each other. Sand-storage dams, science and sustainable development in Kenya. Physics and Chemistry of the Earth, Parts $A / B / C, 34(1-2), 14-22$.

10. Farrell, M. J. (1957). The measurement of productive efficiency. Journal of the Royal Statistical Society: Series A (General), $120(3), 253-281$.

11. Hanson, G., \& Nilsson, Å. (1986). Ground-Water Dams for Rural-Water Supplies in Developing Countries. Groundwater, 24(4), 497-506.

12. Hedayati-Moghadam, Z., Seidayi, S. E., \& Nouri, H. (2014). Multi-criteria analysis for measuring sustainability of rural areas of Isfahan Province, Iran. International Journal of Economics, Commerce and Management, 2(9), 1-14.

13. Ikard, S. J., Revil, A., Schmutz, M., Karaoulis, M., Jardani, A., \& Mooney, M. (2014). Characterization of focused seepage through an earthfill dam using geoelectrical methods. Groundwater, 52(6), 952-965.

14. Ishida, S., Kotoku, M., Abe, E., Fazal, M. A., Tsuchihara, T., \& Imaizumi, M. (2003). Construction of subsurface dams and their impact on the environment. Materials and Geoenvironment, 50, 149-152.

15. Ishida, S., Tsuchihara, T., \& Imaizumi, M. (2006). Fluctuation of NO 3-N in groundwater of the reservoir of the Sunagawa Subsurface Dam, Miyako Island, Japan. Paddy and Water Environment, 4(2), 101-110.

16. Jamali, I. A., Mörtberg, U., Olofsson, B., \& Shafique, M. (2014). A spatial multi-criteria analysis approach for locating suitable sites for construction of subsurface dams in Northern Pakistan. Water Resources Management, 28(14), 5157-5174.

17. Jamali, I. A., Olofsson, B., \& Mörtberg, U. (2013). Locating suitable sites for the construction of subsurface dams using GIS. Environmental Earth Sciences, 70(6), 2511-2525.

18. Jamali, A. A., Randhir, T. O., \& Nosrati, J. (2018). Site suitability analysis for subsurface dams using Boolean and fuzzy logic in arid watersheds. Journal of Water Resources Planning and Management, 144(8), 4018047.

19. Khaki, A. M., Mojaradi, B., Ghobadipour, B., Maghsoudy, S., \& Naghibi, F. (2015). Integration of GIS and analytical hierarchy process method for locating road emergency medical services station. Geosystem Engineering, 18(2), 92-103.

20. Klamler, C. (2005). On the closeness aspect of three voting rules: Borda-Copeland-Maximin. Group Decision and Negotiation, 14(3), 233-240.

21. Lasage, R., Aerts, J., Mutiso, G.-C., \& De Vries, A. (2008). Potential for community based adaptation to droughts: Sand dams in Kitui, Kenya. Physics and Chemistry of the Earth, Parts $A / B / C, 33(1-2), 67-73$.

22. Lozano, S., Iribarren, D., Moreira, M. T., \& Feijoo, G. (2009). The link between operational efficiency and environmental impacts: a joint application of life cycle assessment and data envelopment analysis. Science of the Total Environment, 407(5), 1744-1754.

23. Mohammadi, A., Rafiee, S., Mohtasebi, S. S., Avval, S. H. M., \& Rafiee, H. (2011). Energy efficiency improvement and input cost saving in kiwifruit production using Data Envelopment Analysis approach. Renewable Energy, 36(9), 2573-2579.

24. Mohebali, S., Maghsoudy, S., \& Ardejani, F. D. (2020). Application of data envelopment analysis in environmental impact assessment of a coal washing plant: A new sustainable approach. Environmental Impact Assessment Review, 83, 106389.

25. Mohebali, S., Maghsoudy, S., Ardejani, F. D., \& Shafaei, F. (2019). Developing a coupled environmental impact assessment (C-EIA) method with

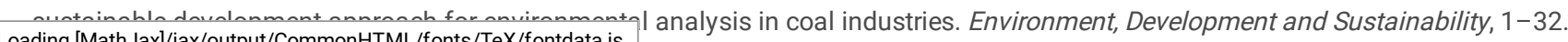


26. Mousavi-Avval, S. H., Mohammadi, A., Rafiee, S., \& Tabatabaeefar, A. (2012). Assessing the technical efficiency of energy use in different barberry production systems. Journal of Cleaner Production, 27, 126-132.

27. Nilsson, A. (1988). Groundwater dams for small-scale water supply. Intermediate Technology Publications.

28. Rahman, M. A., Rusteberg, B., Gogu, R. C., Ferreira, J. P. L., \& Sauter, M. (2012). A new spatial multi-criteria decision support tool for site selection for implementation of managed aquifer recharge. Journal of Environmental Management, 99, 61-75.

29. Rahmani, B., Rahmani, F. A. R., Faraji, S. H. A., \& Rezaee, M. (2016). Exploratory Spatial Data Analysis (Esda) Employment In Rural Settlement (Case Study: Rural Areas Of Isfahan Province).

30. Shafiei, Z., Farsani, N. T., \& Abdollahpour, M. (2017). The benefit of geo-branding in a rural geotourism destination: Isfahan, Iran. Geojournal of Tourism and Geosites, 19, 96-103.

31. Suk, H., Seo, M.-W., \& Kim, H.-S. (2012). Hydrogeological modeling for investigation of factors controlling the storage capacity of groundwater dam. KSCE Journal of Civil Engineering, 16(6), 933-942.

32. Taufiq, A., Rosliani, D., \& Ruswandi, E. (2010). Pre Elementary Evaluation Of Obel-Obel Underground Dam Indonesia.

33. Tzeng, G.-H., \& Huang, J.-J. (2011). Multiple attribute decision making: methods and applications. CRC press.

34. Wang, M., Chen, Y., Xia, X., Li, J., \& Liu, J. (2014). Energy efficiency and environmental performance of bioethanol production from sweet sorghum stem based on life cycle analysis. Bioresource Technology, 163, 74-81.

35. Wu, W. W. (2012). An integrated solution for benchmarking using DEA, gray entropy, and Borda count. The Service Industries Journal, 32(2), 321-335.

\section{Tables}

Table 1

The Efficiency of $D U_{D}$ in different methods for a simple DEA example with four

DMUs with one input and one output

\begin{tabular}{|llll|}
\hline \multirow{2}{*}{ DEA Method } & \multicolumn{2}{l|}{ Efficiency of $\mathrm{DMU}_{\mathrm{D}}$} & \\
\cline { 2 - 4 } & Geometrical Calculation & Values & Final Efficiency \\
\hline CCR-Input oriented & PQ/PD & $2.25 / 4$ & 0.56 \\
\hline BCC-Input oriented & PR/PD & $2.66 / 4$ & 0.66 \\
\hline CCR-Output oriented & TW/TD & $5.3 / 3$ & 1.77 \\
\hline BCC-Output oriented & TS/TD & $5 / 3$ & 1.66 \\
\hline
\end{tabular}

Table 2. Different optimization models for the DEA problem and supper efficiency approaches. 


\begin{tabular}{|c|c|c|}
\hline DEA Approach & \multicolumn{2}{|c|}{ Optimization Model } \\
\hline $\mathrm{CCR}$ input-oriented & $\begin{array}{c}\text { Maximize } \theta_{k}=\frac{\sum_{r-1}^{s} u_{r} y_{r k}}{\sum_{i=1}^{m} v_{i} x_{i t}} \\
\text { Subject to }: \frac{\sum_{r=1}^{s} u_{r} y_{i j}}{\sum_{i=1}^{m} v_{i} x_{i j}} \leq 1 \\
u_{r}, v_{i} \geq 0\end{array}$ & $\begin{array}{l}(j=1,2, \ldots, n) \\
(r=1,2, \ldots, s),(i=1,2, \ldots, m)\end{array}$ \\
\hline CCR output-oriented & $\begin{array}{c}\text { Minimize } \theta_{k}=\frac{\sum_{i=1}^{m} v_{i} x_{i k}}{\sum_{r-1}^{m} u_{r} y_{r k}} \\
\text { Subject to }: \frac{\sum_{i=1}^{m} v_{i} x_{i j}}{\sum_{r=1}^{s} u_{r} y_{r j}} \geq 1 \\
u_{r}, v_{i} \geq 0\end{array}$ & $\begin{array}{l}(j=1,2, \ldots, n) \\
(r=1,2, \ldots, s),(i=1,2, \ldots, m)\end{array}$ \\
\hline $\mathrm{BCC}$ input-oriented & $\begin{array}{c}\text { Maximize } \theta_{k}=\frac{\sum_{r-1}^{s} u_{r} y_{r k}+w}{\sum_{i=1}^{m} v_{i} x_{i k}} \\
\text { Subject to }: \frac{\sum_{r=1}^{x} u_{r} y_{i j}+w}{\sum_{i=1}^{m} v_{i} x_{i j}} \leq 1 \\
u_{r}, v_{i} \geq \mathcal{\varepsilon} \\
\varepsilon>0\end{array}$ & $\begin{array}{l}(j=1,2, \ldots, n) \\
(r=1,2, \ldots, s),(i=1,2, \ldots, m)\end{array}$ \\
\hline BCC output-oriented & 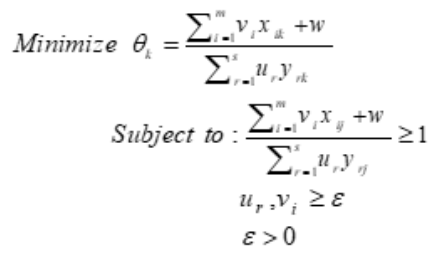 & $\begin{array}{l}(j=1,2, \ldots, n) \\
(r=1,2, \ldots, s),(i=1,2, \ldots, m)\end{array}$ \\
\hline $\begin{array}{l}\text { Super Efficiency } \\
\text { (CCR input-oriented) }\end{array}$ & $\begin{array}{c}\text { Maximize } \theta_{k}=\frac{\sum_{r=1}^{s} u_{r} y_{r k}}{\sum_{i=1}^{m} v_{i} x_{i k}} \\
\text { Subject to }: \frac{\sum_{r-1}^{s} u_{r} y_{r j}}{\sum_{i-1}^{m} v_{i} x_{y}} \leq 1 \\
u_{r}, v_{i} \geq 0\end{array}$ & $\begin{array}{l}(j=1,2, \ldots, n),(j \neq k) \\
(r=1,2, \ldots, s),(i=1,2, \ldots, m)\end{array}$ \\
\hline
\end{tabular}

Table 3

Suggested weights for efficient criteria by 10 experts.

\begin{tabular}{|c|c|c|c|c|c|c|c|c|c|c|c|c|}
\hline \multirow[t]{2}{*}{ Criteria } & \multirow[t]{2}{*}{ Sub-Criteria } & \multicolumn{10}{|c|}{ Suggested weights by 10 experts } & \multirow[t]{2}{*}{ Geometric mean } \\
\hline & & 1 & 2 & 3 & 4 & 5 & 6 & 7 & 8 & 9 & 10 & \\
\hline \multirow[t]{2}{*}{ Climate } & Average annual rainfall (C1) & 7 & 8 & 7 & 8 & 7 & 7 & 4 & 6 & 6 & 5 & 6.374 \\
\hline & Regional climate (C2) & 5 & 5 & 5 & 5 & 7 & 5 & 5 & 6 & 4 & 2 & 4.699 \\
\hline \multirow[t]{3}{*}{ Socio Economy } & Distance from villages (C3) & 3 & 5 & 7 & 6 & 5 & 4 & 5 & 6 & 4 & 3 & 4.631 \\
\hline & Population of downstream villages (C4) & 4 & 6 & 6 & 8 & 6 & 6 & 4 & 7 & 4 & 4 & 5.332 \\
\hline & Area of benefited agricultural lands (C5) & 6 & 6 & 8 & 8 & 6 & 6 & 6 & 7 & 4 & 5 & 6.086 \\
\hline \multirow[t]{3}{*}{ Geology } & Alluvium texture (C6) & 8 & 6 & 9 & 7 & 9 & 9 & 7 & 8 & 5 & 6 & 7.268 \\
\hline & Base lithology (C7) & 9 & 8 & 7 & 7 & 6 & 6 & 8 & 8 & 4 & 5 & 6.624 \\
\hline & Fractures and faults (C8) & 8 & 8 & 6 & 8 & 9 & 5 & 7 & 7 & 6 & 6 & 6.898 \\
\hline \multirow[t]{5}{*}{ Hydrology } & Stream slope (C9) & 8 & 9 & 8 & 9 & 8 & 9 & 9 & 7 & 5 & 4 & 7.366 \\
\hline & Stream flow type (C10) & 5 & 4 & 3 & 5 & 5 & 3 & 2 & 4 & 5 & 3 & 3.743 \\
\hline & Area of upper basin (C11) & 6 & 5 & 7 & 5 & 5 & 5 & 6 & 6 & 6 & 5 & 5.562 \\
\hline & Stream depth (C12) & 9 & 9 & 9 & 9 & 8 & 8 & 9 & 9 & 7 & 7 & 8.360 \\
\hline & Stream width (C13) & 6 & 9 & 8 & 9 & 8 & 8 & 9 & 9 & 6 & 7 & 7.812 \\
\hline
\end{tabular}


Table 4

Primary qualitative decision matrix for groundwater dam site selection

\begin{tabular}{|c|c|c|c|c|c|c|c|c|c|c|}
\hline \multirow[t]{2}{*}{ Criteria } & \multicolumn{10}{|l|}{ Alternatives } \\
\hline & $\mathrm{A} 1$ & A2 & A3 & A4 & A5 & A6 & A7 & A8 & A9 & A10 \\
\hline $\mathrm{C} 1$ & 195.3 & 180 & 121.7 & 125 & 90 & 150 & 98 & 130 & 130 & 140 \\
\hline $\mathrm{C} 2$ & Mediterranean & Mediterranean & Arid & Arid & Arid & Semiarid & Arid & Arid & Arid & Semiarid \\
\hline $\mathrm{C} 3$ & 1200 & 1100 & 1000 & 500 & 300 & 500 & 1200 & 1100 & 800 & 2000 \\
\hline $\mathrm{C} 4$ & 500 & 200 & 50 & 100 & 150 & 50 & 50 & 70 & 70 & 200 \\
\hline C5 & 70 & 30 & 8 & 10 & 15 & 5 & 2 & 50 & 50 & 6 \\
\hline $\mathrm{C} 6$ & $\begin{array}{l}\text { Coarse } \\
\text { grained }\end{array}$ & $\begin{array}{l}\text { Coarse } \\
\text { grained }\end{array}$ & $\begin{array}{l}\text { Coarse } \\
\text { grained }\end{array}$ & $\begin{array}{l}\text { Medium } \\
\text { grained }\end{array}$ & $\begin{array}{l}\text { Coarse } \\
\text { grained }\end{array}$ & $\begin{array}{l}\text { Coarse } \\
\text { grained }\end{array}$ & $\begin{array}{l}\text { Medium } \\
\text { to fine- } \\
\text { grained }\end{array}$ & $\begin{array}{l}\text { Fine- } \\
\text { grained }\end{array}$ & $\begin{array}{l}\text { Fine- } \\
\text { grained }\end{array}$ & $\begin{array}{l}\text { Coarse } \\
\text { grained }\end{array}$ \\
\hline $\mathrm{C7}$ & Granodiorite & $\begin{array}{l}\text { Marl stone- } \\
\text { Tuff }\end{array}$ & $\begin{array}{l}\text { Basic } \\
\text { igneous }\end{array}$ & $\begin{array}{l}\text { Ignimbrite- } \\
\text { Tuff }\end{array}$ & Limestone & Igneous & $\begin{array}{l}\text { Basic } \\
\text { igneous }\end{array}$ & $\begin{array}{l}\text { Limestone- } \\
\text { granite }\end{array}$ & $\begin{array}{l}\text { Limestone- } \\
\text { andesite }\end{array}$ & Andesite \\
\hline $\mathrm{C} 8$ & Yes & Yes & No & Yes & No & Yes & Yes & No & No & Yes \\
\hline $\mathrm{C} 9$ & 4 & 4 & 4 & 4 & 2 & 5 & 3 & 3 & 3 & 4 \\
\hline C10 & Seasonal & Seasonal & Seasonal & Seasonal & Torrential & Torrential & Seasonal & Seasonal & Seasonal & Torrential \\
\hline C11 & 15295 & 1898 & 5560 & 3420 & 6828 & 5864 & 1921 & 8204 & 6466 & 11738 \\
\hline C12 & 45 & 13 & 15 & 10 & 15 & 30 & 8 & 15 & 15 & 25 \\
\hline C13 & 70 & 30 & 50 & 40 & 115 & 50 & 20 & 50 & 50 & 70 \\
\hline
\end{tabular}

* Dimension of the C1 is (mm/year), C5 is (ha), C3, C12, and C13 is ( $\mathrm{m}), \mathrm{C} 9$ is (\%), C11 is $\left(\mathrm{m}^{2}\right)$.

* $\mathrm{C} 1, \mathrm{C} 3$, and $\mathrm{C} 9$ are negative factors, and the others are positive.

Table 5

Final quantitative decision matrix has been used in Hybrid-MCDM method

\begin{tabular}{|llllllllllllll||}
\hline & C1 & C2 & C3 & C4 & C5 & C6 & C7 & C8 & C9 & C10 & C11 & C12 & C13 \\
\hline Tameh (A1) & 195.3 & 0.4 & 1200 & 500 & 70 & 0.8 & 0.6 & 0.1 & 4 & 0.6 & 15295 & 45 & 70 \\
\hline Jazn (A2) & 180 & 0.4 & 1100 & 200 & 30 & 0.8 & 0.3 & 1 & 4 & 0.6 & 1898 & 13 & 30 \\
\hline Mehrabad (A3) & 121.7 & 0.6 & 1000 & 50 & 8 & 0.8 & 0.6 & 1 & 4 & 0.6 & 5560 & 15 & 50 \\
\hline Mastbandi (A4) & 125 & 0.6 & 500 & 100 & 10 & 0.6 & 0.5 & 0.1 & 4 & 0.6 & 3420 & 10 & 40 \\
\hline Hoseinabad (A5) & 90 & 0.6 & 300 & 150 & 15 & 0.8 & 0.4 & 1 & 2 & 0.4 & 6828 & 15 & 115 \\
\hline Zaghal (A6) & 150 & 0.5 & 500 & 50 & 5 & 0.8 & 0.6 & 0.1 & 5 & 0.4 & 5864 & 30 & 50 \\
\hline Kadouseh (A7) & 98 & 0.6 & 1200 & 50 & 2 & 0.5 & 0.6 & 0.1 & 3 & 0.6 & 1921 & 8 & 20 \\
\hline Khoramabad-1 (A8) & 130 & 0.6 & 1100 & 70 & 50 & 0.2 & 0.4 & 1 & 3 & 0.6 & 8204 & 15 & 50 \\
\hline Khoramabad-2 (A9) & 130 & 0.6 & 800 & 70 & 50 & 0.2 & 0.4 & 1 & 3 & 0.6 & 6466 & 15 & 50 \\
\hline Darbagh (A10) & 140 & 0.5 & 2000 & 200 & 6 & 0.8 & 0.6 & 0.1 & 4 & 0.4 & 11738 & 25 & 70 \\
\hline
\end{tabular}


Table 6

Final results of applying different MCDM approaches in SSD site selection

\begin{tabular}{|c|c|c|c|c|c|}
\hline AHP & & Monte AHP & & FAHP & \\
\hline Tameh (A1) & 0.145 & Tameh (A1) & 0.145 & Tameh (A1) & 0.145 \\
\hline Hoseinabad (A5) & 0.131 & Hoseinabad (A5) & 0.132 & Hoseinabad (A5) & 0.132 \\
\hline Khoramabad-1 (A8) & 0.102 & Khoramabad-1 (A8) & 0.102 & Khoramabad-1 (A8) & 0.103 \\
\hline Khoramabad-2 (A9) & 0.102 & Khoramabad-2 (A9) & 0.102 & Khoramabad-2 (A9) & 0.102 \\
\hline Darbagh (A10) & 0.098 & Darbagh (A10) & 0.097 & Darbagh (A10) & 0.098 \\
\hline Mehrabad (A3) & 0.096 & Mehrabad (A3) & 0.096 & Mehrabad (A3) & 0.096 \\
\hline Jazn (A2) & 0.091 & Jazn (A2) & 0.091 & Jazn (A2) & 0.091 \\
\hline Zaghal (A6) & 0.088 & Zaghal (A6) & 0.088 & Zaghal (A6) & 0.088 \\
\hline Mastbandi (A4) & 0.078 & Mastbandi (A4) & 0.079 & Mastbandi (A4) & 0.078 \\
\hline Kadouseh (A7) & 0.068 & Kadouseh (A7) & 0.068 & Kadouseh (A7) & 0.068 \\
\hline TOPSIS & & FTOPSIS & & PROMETHEE II & \\
\hline Tameh (A1) & 0.673 & Hoseinabad (A5) & 0.143 & Hoseinabad (A5) & 20.7 \\
\hline Hoseinabad (A5) & 0.518 & Tameh (A1) & 0.141 & Tameh (A1) & 17.2 \\
\hline Khoramabad-2 (A9) & 0.424 & Mehrabad (A3) & 0.111 & Mehrabad (A3) & 7.5 \\
\hline Khoramabad-1 (A8) & 0.423 & Khoramabad-1 (A8) & 0.093 & Khoramabad-1 (A8) & 3.1 \\
\hline Darbagh (A10) & 0.405 & Khoramabad-2 (A9) & 0.093 & Khoramabad-2 (A9) & 2.7 \\
\hline Mehrabad (A3) & 0.376 & Darbagh (A10) & 0.093 & Darbagh (A10) & 1.7 \\
\hline Jazn (A2) & 0.373 & Zaghal (A6) & 0.089 & Zaghal (A6) & -10.3 \\
\hline Zaghal (A6) & 0.371 & Kadouseh (A7) & 0.084 & Kadouseh (A7) & -10.4 \\
\hline Mastbandi (A4) & 0.281 & Mastbandi (A4) & 0.080 & Mastbandi (A4) & -12.6 \\
\hline Kadouseh (A7) & 0.238 & Jazn (A2) & 0.072 & Jazn (A2) & -19.4 \\
\hline ELECTRE I & & ELECTRE II & & ELECTRE III & \\
\hline Tameh (A1) & 8 & Tameh (A1) & 12 & Hoseinabad (A5) & 1.78 \\
\hline Hoseinabad (A5) & 8 & Hoseinabad (A5) & 11 & Tameh (A1) & 0 \\
\hline Mehrabad (A3) & 2 & Mehrabad (A3) & 2 & Jazn (A2) & 0 \\
\hline Khoramabad-1 (A8) & 1 & Khoramabad-1 (A8) & 0 & Zaghal (A6) & 0 \\
\hline Khoramabad-2 (A9) & 1 & Khoramabad-2 (A9) & 0 & Kadouseh (A7) & 0 \\
\hline Jazn (A2) & -1 & Darbagh (A10) & -1 & Khoramabad-1 (A8) & 0 \\
\hline Darbagh (A10) & -2 & Jazn (A2) & -2 & Khoramabad-2 (A9) & 0 \\
\hline Zaghal (A6) & -4 & Mastbandi (A4) & -4 & Darbagh (A10) & 0 \\
\hline Mastbandi (A4) & -4 & Zaghal (A6) & -7 & Mehrabad (A3) & -0.87 \\
\hline Kadouseh (A7) & -9 & Kadouseh (A7) & -11 & Mastbandi (A4) & -0.91 \\
\hline
\end{tabular}


Table 7

Ranking of alternatives in different methods and average score as a coupling strategy

\begin{tabular}{|c|c|c|c|c|c|c|c|c|c|c|}
\hline & AHP & MAHP & FAHP & TOPSIS & FTOPSIS & ELECTRE I & ELECTRE II & ELECTRE III & PROMETHEE II & Average Score \\
\hline Tameh (A1) & 1 & 1 & 1 & 1 & 2 & 1 & 1 & 2 & 2 & 1.3 \\
\hline Jazn (A2) & 7 & 7 & 7 & 7 & 10 & 6 & 7 & 3 & 10 & 7.1 \\
\hline Mehrabad (A3) & 6 & 6 & 6 & 6 & 3 & 3 & 3 & 9 & 3 & 5.0 \\
\hline Mastbandi (A4) & 9 & 9 & 9 & 9 & 9 & 9 & 8 & 10 & 9 & 9.0 \\
\hline Hoseinabad (A5) & 2 & 2 & 2 & 2 & 1 & 2 & 2 & 1 & 1 & 1.7 \\
\hline Zaghal (A6) & 8 & 8 & 8 & 8 & 7 & 8 & 9 & 4 & 7 & 7.4 \\
\hline Kadouseh (A7) & 10 & 10 & 10 & 10 & 8 & 10 & 10 & 5 & 8 & 9.0 \\
\hline Khoramabad-1 (A8) & 3 & 3 & 3 & 4 & 4 & 4 & 4 & 6 & 4 & 3.9 \\
\hline Khoramabad-2 (A9) & 4 & 4 & 4 & 3 & 5 & 5 & 5 & 7 & 5 & 4.7 \\
\hline Darbagh (A10) & 5 & 5 & 5 & 5 & 6 & 7 & 6 & 8 & 6 & 5.9 \\
\hline
\end{tabular}

Table 8

Calculating Borda score for different alternatives of groundwater dam site selection

\begin{tabular}{|lccccccccccc|}
\hline & A1 & A2 & A3 & A4 & A5 & A6 & A7 & A8 & A9 & A10 & Borda Score \\
\hline Tameh (A1) & $\ldots$ & 9 & 9 & 9 & 3 & 9 & 9 & 9 & 9 & 9 & 75 \\
\hline Jazn (A2) & -9 & $\ldots$ & -7 & 5 & -9 & 5 & 5 & -7 & -7 & -5 & -29 \\
\hline Mehrabad (A3) & -9 & 7 & $\ldots$ & 9 & -9 & 7 & 7 & -1 & -1 & -1 & 9 \\
\hline Mastbandi (A4) & -9 & -5 & -9 & $\ldots$ & -9 & -7 & 3 & -9 & -9 & -9 & -63 \\
\hline Hoseinabad (A5) & -3 & 9 & 9 & 9 & $\ldots$ & 9 & 9 & 9 & 9 & 9 & 69 \\
\hline Zaghal (A6) & -9 & -5 & -7 & -3 & -9 & $\ldots$ & -9 & -7 & -7 & -7 & -63 \\
\hline Kadouseh (A7) & -9 & -5 & -7 & -3 & -9 & -9 & $\ldots$ & -7 & -7 & -7 & -63 \\
\hline Khoramabad-1 (A8) & -9 & 7 & 1 & 9 & -9 & 7 & 7 & $\ldots$ & 7 & 9 & 29 \\
\hline Khoramabad-2 (A9) & -9 & 7 & 1 & 9 & -9 & 7 & 7 & -7 & $\ldots$ & 9 & 15 \\
\hline Darbagh (A10) & -9 & 5 & 1 & 9 & -9 & 7 & 7 & -9 & -9 & $\ldots$ & -7 \\
\hline
\end{tabular}

Table 9

Calculating Copeland score for different alternatives of groundwater dam site selection

\begin{tabular}{|lccccccccccc|}
\hline & A1 & A2 & A3 & A4 & A5 & A6 & A7 & A8 & A9 & A10 & Copeland Score \\
\hline Tameh (A1) & $\ldots$ & 1 & 1 & 1 & 1 & 1 & 1 & 1 & 1 & 1 & 9 \\
\hline Jazn (A2) & -1 & $\ldots$ & -1 & 1 & -1 & 1 & 1 & -1 & -1 & -1 & -3 \\
\hline Mehrabad (A3) & -1 & 1 & $\ldots$ & 1 & -1 & 1 & 1 & -1 & -1 & -1 & -1 \\
\hline Mastbandi (A4) & -1 & -1 & -1 & $\ldots$ & -1 & -1 & 1 & -1 & -1 & -1 & -7 \\
\hline Hoseinabad (A5) & -1 & 1 & 1 & 1 & $\ldots$ & 1 & 1 & 1 & 1 & 1 & 7 \\
\hline Zaghal (A6) & -1 & -1 & -1 & -1 & -1 & $\ldots$ & -1 & -1 & -1 & -1 & -9 \\
\hline Kadouseh (A7) & -1 & -1 & -1 & -1 & -1 & -1 & $\ldots$ & -1 & -1 & -1 & -9 \\
\hline Khoramabad-1 (A8) & -1 & 1 & 1 & 1 & -1 & 1 & 1 & $\ldots$ & 1 & 1 & 5 \\
\hline Khoramabad-2 (A9) & -1 & 1 & 1 & 1 & -1 & 1 & 1 & -1 & $\ldots$ & 1 & 3 \\
\hline
\end{tabular}


Table 10

Final groundwater dam ranking with hybrid-MCDM applying coupling strategies

\begin{tabular}{|c|c|c|c|c|c|c|}
\hline Average & & Borda & & Copeland & & Final MCDM Rank \\
\hline Tameh (A1) & 1.3 & Tameh (A1) & 75 & Tameh (A1) & 9 & Tameh (A1) \\
\hline Hoseinabad (A5) & 1.7 & Hoseinabad (A5) & 69 & Hoseinabad (A5) & 7 & Hoseinabad (A5) \\
\hline Khoramabad-1 (A8) & 3.9 & Khoramabad-1 (A8) & 29 & Khoramabad-1 (A8) & 5 & Khoramabad-1 (A8) \\
\hline Khoramabad-2 (A9) & 4.7 & Khoramabad-2 (A9) & 15 & Khoramabad-2 (A9) & 3 & Khoramabad-2 (A9) \\
\hline Mehrabad (A3) & 5.0 & Mehrabad (A3) & 9 & Darbagh (A10) & 1 & Mehrabad (A3) \\
\hline Darbagh (A10) & 5.9 & Darbagh (A10) & -7 & Mehrabad (A3) & -1 & Darbagh (A10) \\
\hline Jazn (A2) & 7.1 & Jazn (A2) & -29 & Jazn (A2) & -3 & Jazn (A2) \\
\hline Zaghal (A6) & 7.4 & Zaghal (A6) & -63 & Mastbandi (A4) & -7 & Zaghal (A6) \\
\hline Kadouseh (A7) & 9.0 & Kadouseh (A7) & -63 & Zaghal (A6) & -9 & Kadouseh (A7) \\
\hline Mastbandi (A4) & 9.0 & Mastbandi (A4) & -63 & Kadouseh (A7) & -9 & Mastbandi (A4) \\
\hline Average & \multicolumn{6}{|c|}{$\mathrm{A} 1>\mathrm{A} 5>\mathrm{A} 8>\mathrm{A} 9>\mathrm{A} 3>\mathrm{A} 10>\mathrm{A} 2>\mathrm{A} 6>\mathrm{A} 7>\mathrm{A} 4$} \\
\hline Borda & \multicolumn{6}{|c|}{$\mathrm{A} 1>\mathrm{A} 5>\mathrm{A} 8>\mathrm{A} 9>\mathrm{A} 3>\mathrm{A} 10>\mathrm{A} 2>\mathrm{A} 6>\mathrm{A} 7>\mathrm{A} 4$} \\
\hline Copeland & \multicolumn{6}{|c|}{$\mathrm{A} 1>\mathrm{A} 5>\mathrm{A} 8>\mathrm{A} 9>\mathrm{A} 10>\mathrm{A} 3>\mathrm{A} 2>\mathrm{A} 4>\mathrm{A} 6>\mathrm{A} 7$} \\
\hline Final MCDM Rank & \multicolumn{6}{|c|}{$\mathrm{A} 1>\mathrm{A} 5>\mathrm{A} 8>\mathrm{A} 9>\mathrm{A} 3>\mathrm{A} 10>\mathrm{A} 2>\mathrm{A} 6>\mathrm{A} 7>\mathrm{A} 4$} \\
\hline
\end{tabular}

Table 11

Simple DEA approach and the efficiency scores and final ranking of the groundwater dam alternatives in different approaches

\begin{tabular}{|llllllll|}
\hline CCR-Min Input & & CCR-Max Output & & BCC-Min Input & & BCC-Max Output \\
\hline Hoseinabad (A5) & 479.5 & Hoseinabad (A5) & 479.5 & Hoseinabad (A5) & 1000 & Hoseinabad (A5) & 1000 \\
\hline Tameh (A1) & 190.7 & Tameh (A1) & 190.7 & Tameh (A1) & 1000 & Tameh (A1) & 279.9 \\
\hline Kadouseh (A7) & 126.8 & Kadouseh (A7) & 126.8 & Khoramabad-1 (A8) & 1000 & Zaghal (A6) & 138.5 \\
\hline Khoramabad-2 (A9) & 123.5 & Khoramabad-2 (A9) & 123.5 & Darbagh (A10) & 1000 & Kadouseh (A7) & 133.2 \\
\hline Zaghal (A6) & 120 & Zaghal (A6) & 120 & Mastbandi (A4) & 1000 & Mehrabad (A3) & 132.1 \\
\hline Khoramabad-1 (A8) & 109.4 & Khoramabad-1 (A8) & 109.4 & Mehrabad (A3) & 1000 & Mastbandi (A4) & 131.2 \\
\hline Darbagh (A10) & 109.2 & Darbagh (A10) & 109.2 & Jazn (A2) & 1000 & Khoramabad-2 (A9) & 124.2 \\
\hline Mastbandi (A4) & 105 & Mastbandi (A4) & 105 & Zaghal (A6) & 220 & Jazn (A2) & 118.7 \\
\hline Mehrabad (A3) & 100.1 & Mehrabad (A3) & 100.1 & Khoramabad-2 (A9) & 137.5 & Darbagh (A10) & 115.4 \\
\hline Jazn (A2) & 79.8 & Jazn (A2) & 79.8 & Kadouseh (A7) & 133.3 & Khoramabad-1 (A8) & 110.2 \\
\hline
\end{tabular}


Table 12

Decision matrix for DEA analysis with socio-economic approaches

\begin{tabular}{|c|c|c|c|c|c|c|c|c|c|c|c|c|c|}
\hline & $\mathrm{C} 1$ & $\mathrm{C} 2$ & C3 & C4 & C5 & $\mathrm{C6}$ & $\mathrm{C7}$ & $\mathrm{C} 8$ & $\mathrm{Cg}$ & C10 & $\mathrm{C} 11$ & C12 & $\mathrm{C} 13$ \\
\hline Tameh (A1) & 0.144 & 0.132 & 0.061 & 0.347 & 0.285 & 0.059 & 0.079 & 0.182 & 0.111 & 0.087 & 0.029 & 0.033 & 0.063 \\
\hline Jazn (A2) & 0.132 & 0.132 & 0.067 & 0.139 & 0.122 & 0.059 & 0.157 & 0.018 & 0.111 & 0.087 & 0.233 & 0.116 & 0.148 \\
\hline Mehrabad (A3) & 0.089 & 0.088 & 0.074 & 0.035 & 0.033 & 0.059 & 0.079 & 0.018 & 0.111 & 0.087 & 0.080 & 0.100 & 0.089 \\
\hline Mastbandi (A4) & 0.092 & 0.088 & 0.147 & 0.069 & 0.041 & 0.079 & 0.094 & 0.182 & 0.111 & 0.087 & 0.129 & 0.151 & 0.111 \\
\hline Hoseinabad (A5) & 0.066 & 0.088 & 0.245 & 0.104 & 0.061 & 0.059 & 0.118 & 0.018 & 0.056 & 0.130 & 0.065 & 0.100 & 0.039 \\
\hline Zaghal (A6) & 0.110 & 0.105 & 0.147 & 0.035 & 0.020 & 0.059 & 0.079 & 0.182 & 0.139 & 0.130 & 0.075 & 0.050 & 0.089 \\
\hline Kadouseh (A7) & 0.072 & 0.088 & 0.061 & 0.035 & 0.008 & 0.094 & 0.079 & 0.182 & 0.083 & 0.087 & 0.230 & 0.188 & 0.222 \\
\hline Khoramabad-1 (A8) & 0.096 & 0.088 & 0.067 & 0.049 & 0.203 & 0.236 & 0.118 & 0.018 & 0.083 & 0.087 & 0.054 & 0.100 & 0.089 \\
\hline Khoramabad-2 (A9) & 0.096 & 0.088 & 0.092 & 0.049 & 0.203 & 0.236 & 0.118 & 0.018 & 0.083 & 0.087 & 0.068 & 0.100 & 0.089 \\
\hline Darbagh (A10) & 0.103 & 0.105 & 0.037 & 0.139 & 0.024 & 0.059 & 0.079 & 0.182 & 0.111 & 0.130 & 0.038 & 0.060 & 0.063 \\
\hline
\end{tabular}

Table 13

Socio-Economic DEA approach and the final score for different groundwater dam sites

\begin{tabular}{|llllllll|}
\hline CCR-Min Input & & CCR-Max Output & & BCC-Min Input & & \multicolumn{2}{l|}{ BCC-Max Output } \\
\hline Tameh (A1) & 730.3 & Tameh (A1) & 730.3 & Tameh (A1) & 1000 & Tameh (A1) & 1000 \\
\hline Hoseinabad (A5) & 684.8 & Hoseinabad (A5) & 684.8 & Hoseinabad (A5) & 1000 & Hoseinabad (A5) & 1000 \\
\hline Khoramabad-1 (A8) & 378.8 & Khoramabad-1 (A8) & 378.8 & Khoramabad-1 (A8) & 558.5 & Zaghal (A6) & 1000 \\
\hline Jazn (A2) & 189.2 & Jazn (A2) & 189.2 & Jazn (A2) & 262 & Kadouseh (A7) & 1000 \\
\hline Zaghal (A6) & 120 & Zaghal (A6) & 120 & Mehrabad (A3) & 146.8 & Mehrabad (A3) & 1000 \\
\hline Mastbandi (A4) & 90.9 & Mastbandi (A4) & 90.9 & Zaghal (A6) & 128.6 & Darbagh (A10) & 1000 \\
\hline Khoramabad-2 (A9) & 59.3 & Khoramabad-2 (A9) & 59.3 & Mastbandi (A4) & 120.1 & Khoramabad-1 (A8) & 1000 \\
\hline Darbagh (A10) & 57.2 & Darbagh (A10) & 57.2 & Kadouseh (A7) & 114.4 & Jazn (A2) & 397.1 \\
\hline Mehrabad (A3) & 51.9 & Mehrabad (A3) & 51.9 & Darbagh (A10) & 114 & Mastbandi (A4) & 193.3 \\
\hline Kadouseh (A7) & 39 & Kadouseh (A7) & 39 & Khoramabad-2 (A9) & 106.2 & Khoramabad-2 (A9) & 137.3 \\
\hline
\end{tabular}

Table 14. Efficient alternatives in the Socio-Economic DEA approach and the comparison betweer standard efficiency and supper efficiency scores.

\begin{tabular}{lccc}
\hline \multicolumn{1}{c}{$\begin{array}{c}\text { DEA } \\
\text { (CCR-Max Output) }\end{array}$} & $\begin{array}{c}\text { Standard Efficiency } \\
\text { Scores }\end{array}$ & $\begin{array}{c}\text { Supper Efficiency } \\
\text { Scores }\end{array}$ & Efficient Alternatives \\
\hline Tameh (A1) & 100 & 730.3 & 0 \\
Hoseinabad (A5) & 100 & 684.8 & 0 \\
Khoramabad-1 (A8) & 100 & 378.8 & 0 \\
Jazn (A2) & 100 & 189.2 & $\circ$ \\
Zaghal (A6) & 100 & 120.0 & 0 \\
Mastbandi (A4) & 90.9 & 90.9 & - \\
Khoramabad-2 (A9) & 59.3 & 59.3 & - \\
Darbagh (A10) & 57.2 & 57.2 & - \\
Mehrabad (A3) & 51.9 & 51.9 & - \\
Kadouseh (A7) & 39.0 & 39.0 & - \\
\hline
\end{tabular}


Table 15

Potential improvement values and optimum target values for the "Tameh (A1)" DMU in the CCR model (maximize-output) of the Socio-Economic DEA approach.

\begin{tabular}{|llll|}
\hline Criteria & Value & Target & Potential Improvement (\%) \\
\hline Average annual rainfall (C1) & 0.144 & 0.04467 & -68.98 \\
\hline Regional climate (C2) & 0.132 & 0.04397 & -66.69 \\
\hline Distance from villages (C3) & 0.061 & 0.0212 & -65.25 \\
\hline Population of downstream villages (C4) & 0.374 & 0.0512 & -86.31 \\
\hline Area of benefited agricultural lands (C5) & 0.285 & 0.03901 & -86.31 \\
\hline Alluvium texture (C6) & 0.059 & 0.054255 & -8.04 \\
\hline Base lithology (C7) & 0.079 & 0.041282 & -47.74 \\
\hline Fractures and faults (C8) & 0.182 & 0.0549 & -69.84 \\
\hline Stream slope (C9) & 0.111 & 0.04489 & -59.56 \\
\hline Stream flow type (C10) & 0.087 & 0.05096 & -41.43 \\
\hline Area of upper basin (C11) & 0.029 & 0.01942 & -33.03 \\
\hline Stream depth (C12) & 0.033 & 0.033 & 0 \\
\hline Stream width (C13) & 0.063 & 0.03212 & -49.02 \\
\hline
\end{tabular}

\section{Figures}

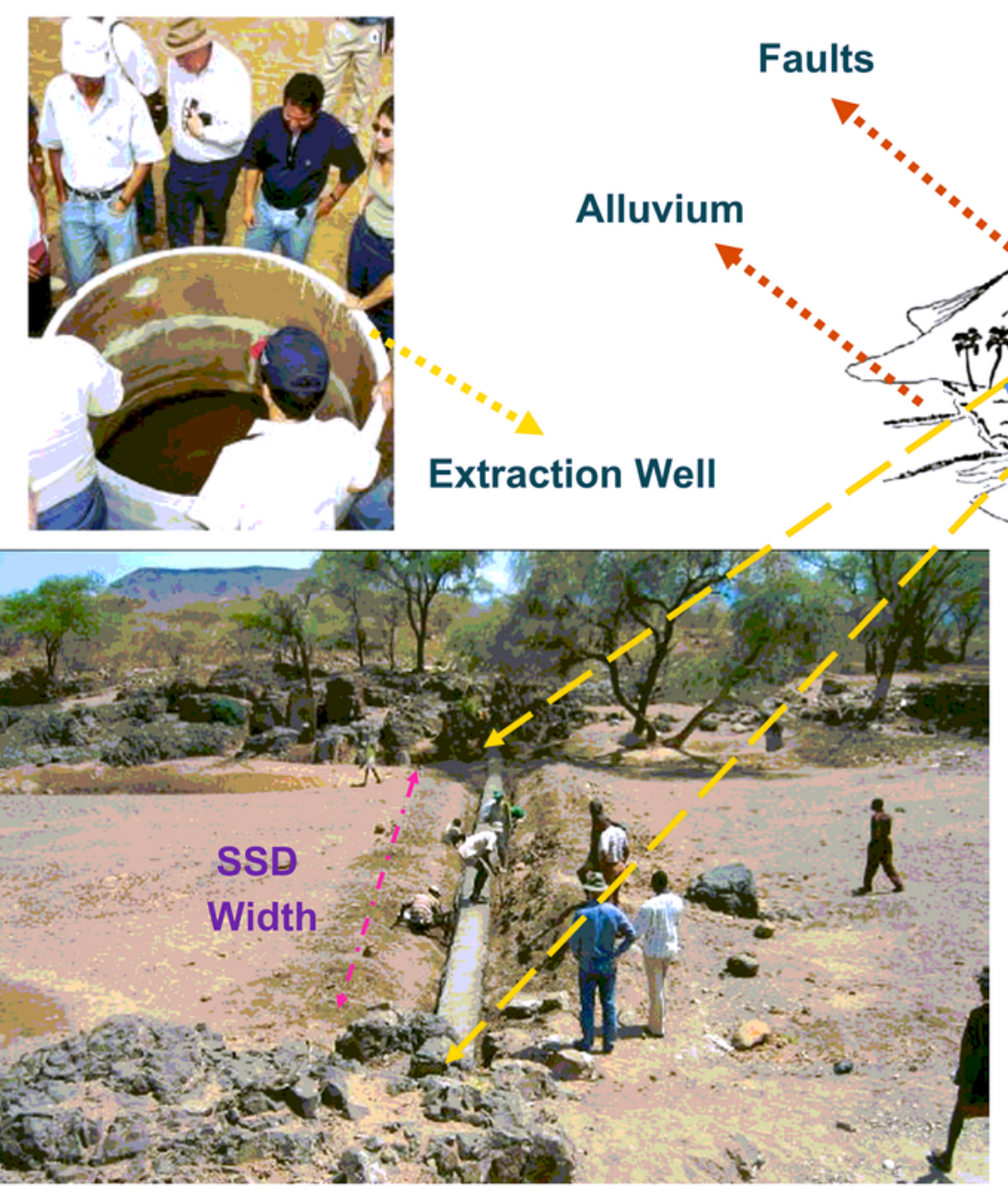


Figure 1

A schematic representation of the groundwater dam's construction methods and the criteria for the site selection.

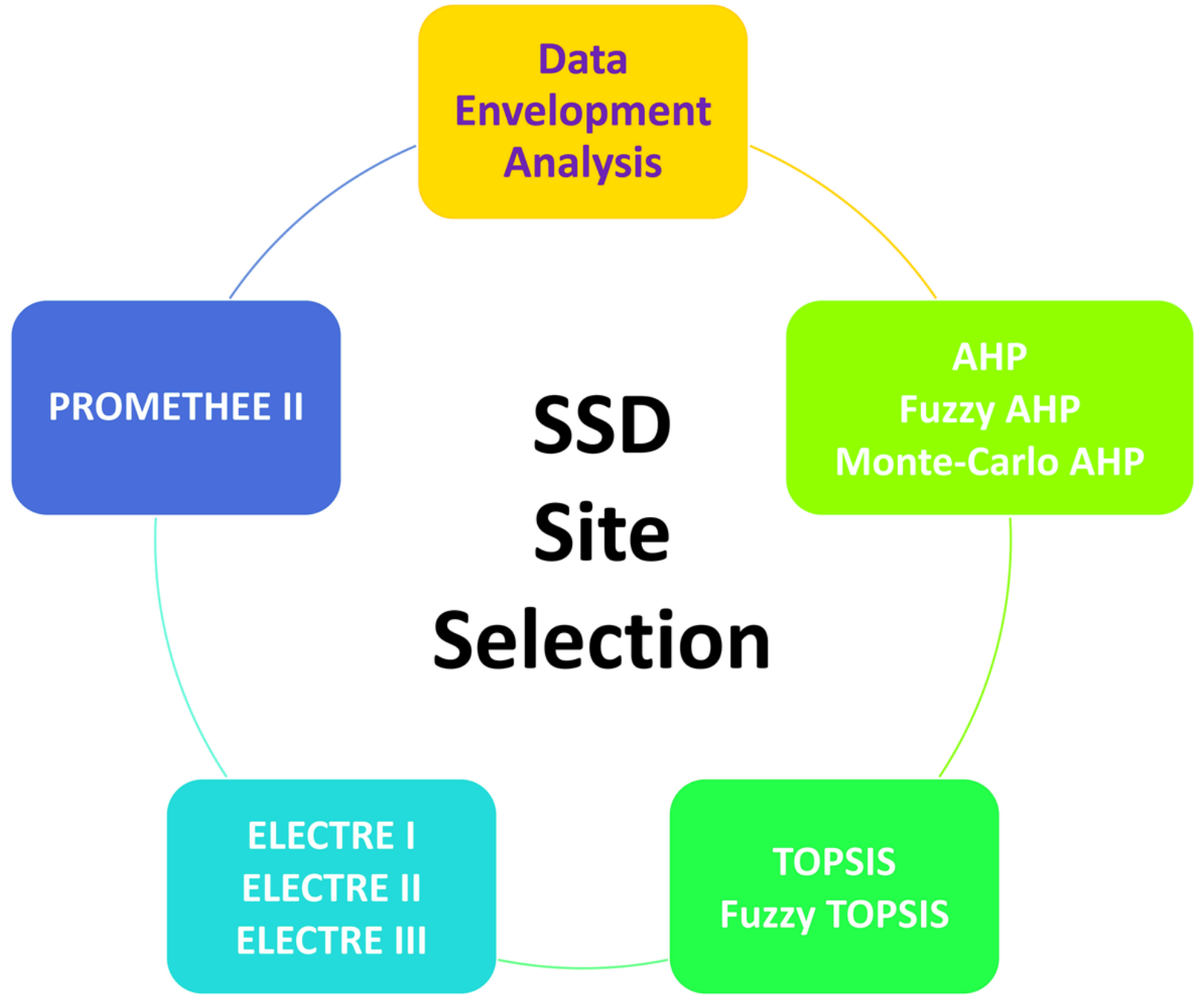

Figure 2

Different MCDM methods were used for groundwater dam site selection in comparison to data envelopment analysis.
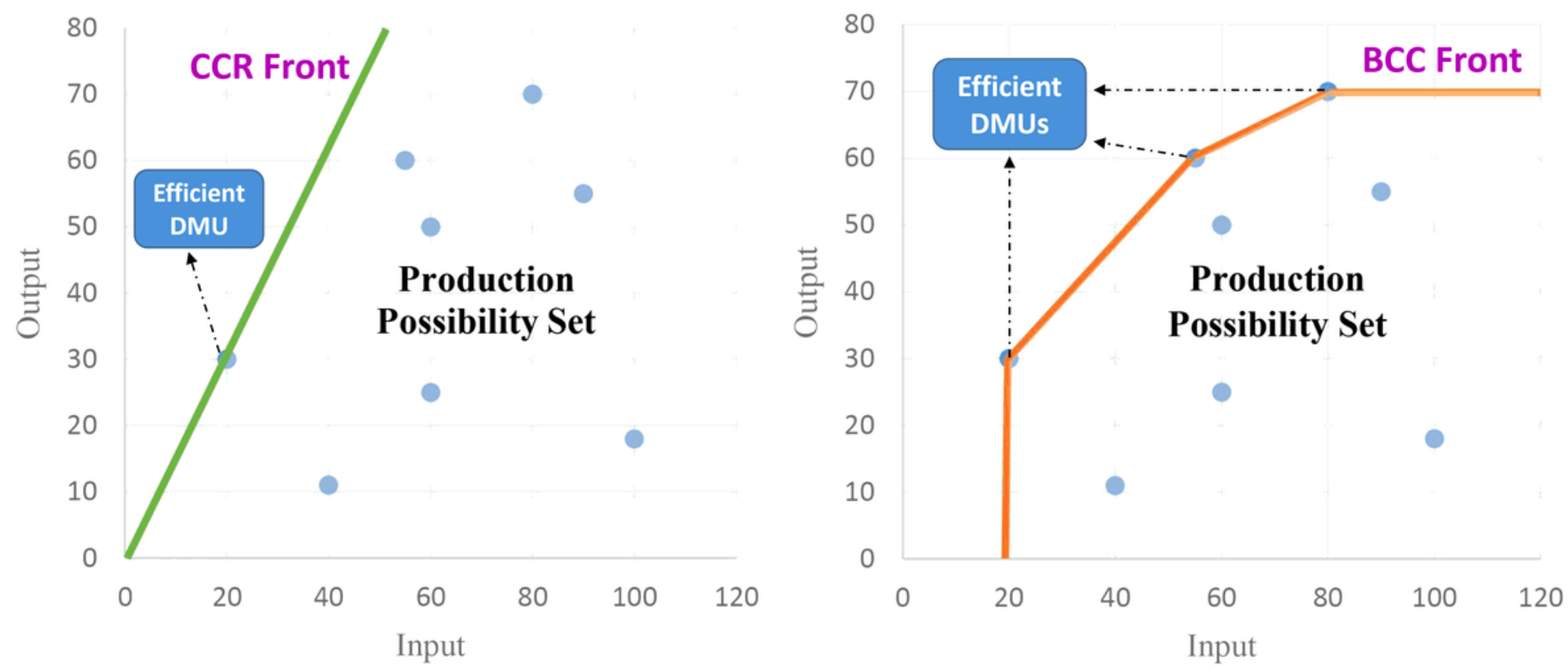
Figure 3

Production possibility set and the efficiency front of the BCC and CCR methods of DEA approach

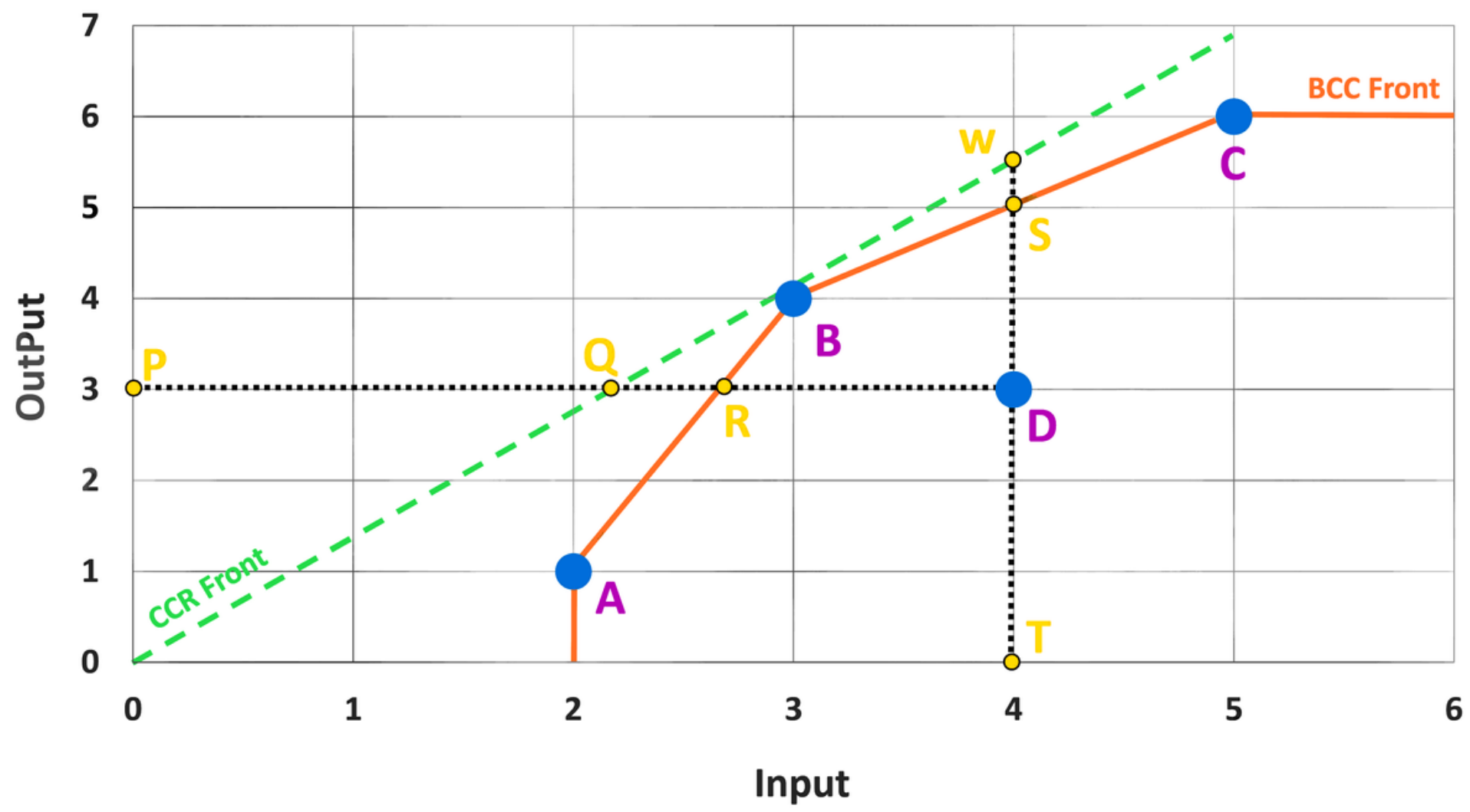

Figure 4

A simple DEA example with four DMUs, DEA efficiency front and calculating the efficiency for each DMUs in different DEA approach (EA,B,C=1) (Modified after Cooper 2006( 

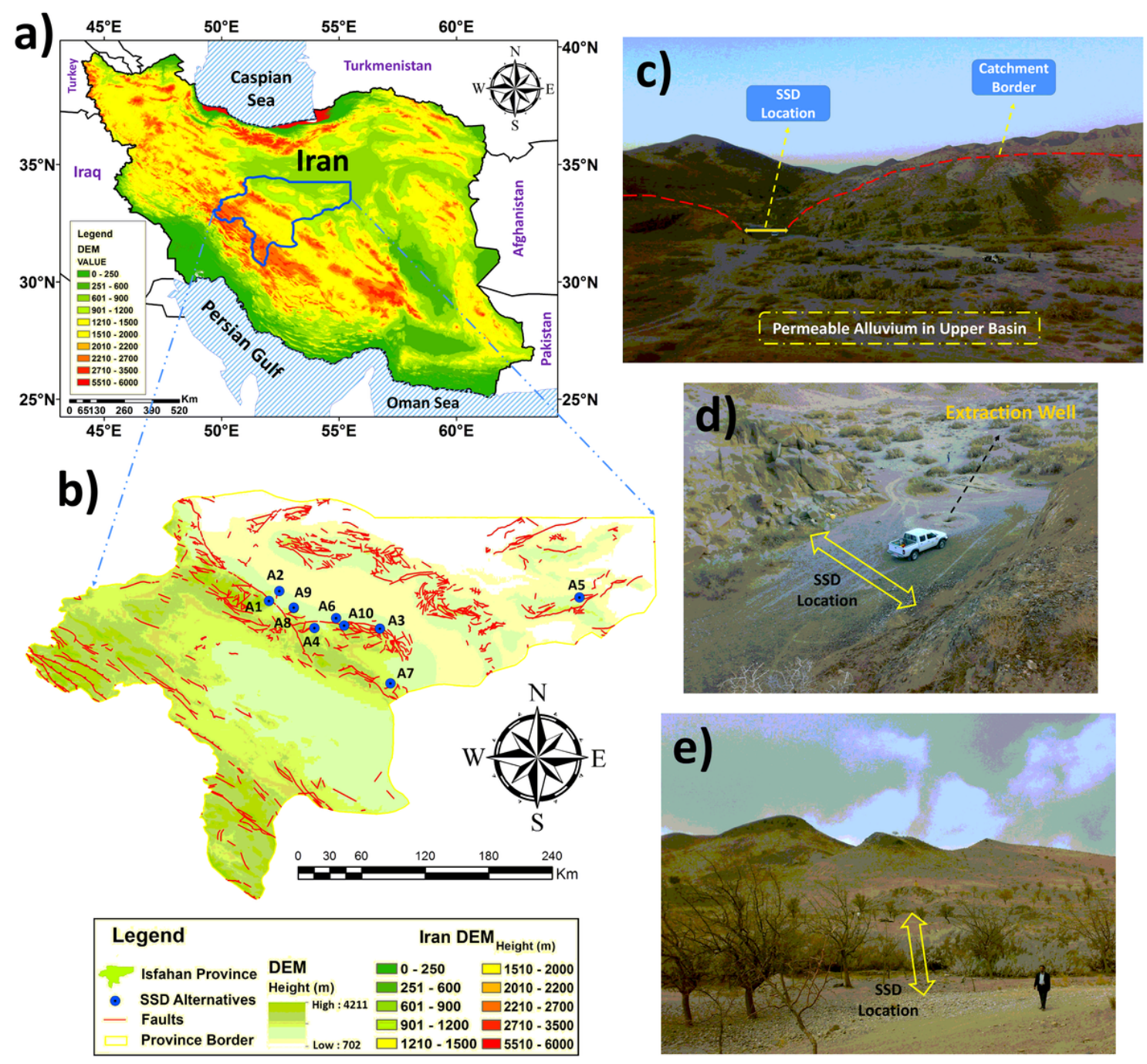

\section{Figure 5}

Location of the Isfahan province in Iran (a), digital elevation model (DEM) of the study area, faults location, and 10 alternatives for groundwater dam construction (b), different characteristics of an underground dam in real images (c, d, e). 


\section{Important Criteria in Groundwater Dam Site Selection}

Climate

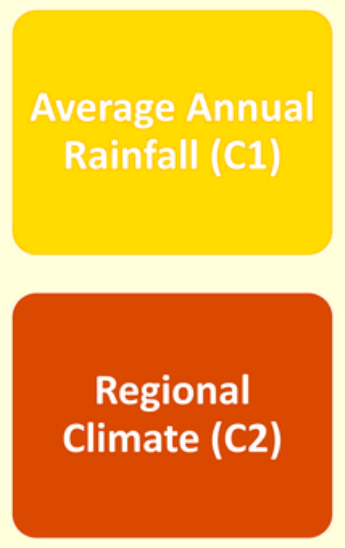

Socio-Economy
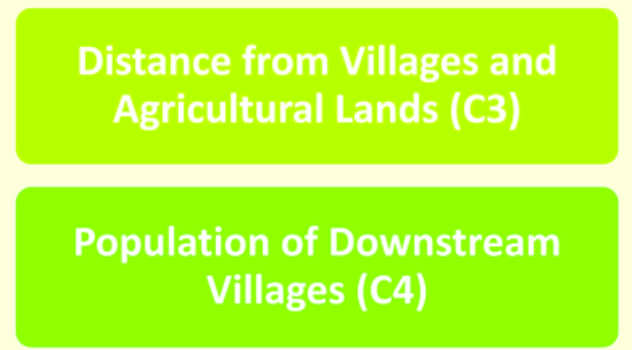

Area of Benefited Agricultural Lands (C5)
Geology

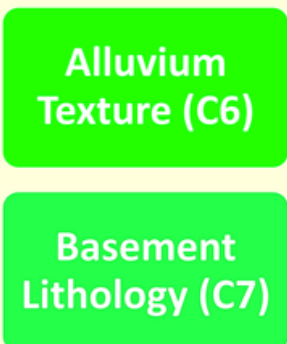

Fractures and Faults (C8)
Hydrology

Stream Slope (C9)

Stream Flow Type

(C10)

Area of Upper

Basin (C11)

Stream Depth (C12)

Stream Width

(C13)

Figure 6

Four categories of 13 important criteria in groundwater Odam site selection.

C9

$(1)$

\section{Stream Slope}

C3

Distance from Villages

C1

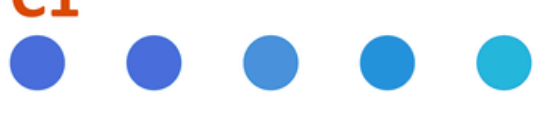

\section{Average Annual Rainfall}

Figure 7

Simple DEA approach for groundwater dam site selection
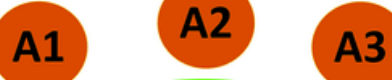

\section{CCR}

Input

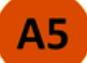

Simple DEA

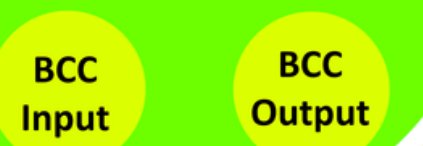

A6

A7 $\begin{array}{lll}\text { C2 } & \mathrm{C} 4 & \mathrm{C7} \\ \mathrm{C} 6 & \mathrm{C} 5 & \mathrm{C} 8\end{array}$

C11 C12

C10 C13 
C1 C6 C8

\section{C2 C7 C9}

\section{C10 C12}

\section{C11 C13}

\section{A3}

A4

A2

A1

CCR

Input

CCR

Output

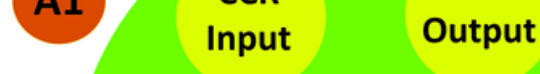

\section{Distance from Villages}

\section{Socio-Economic} DEA

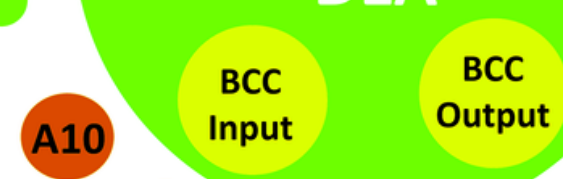

A9

\section{Population of Downstream}

Figure 8

Socio-Economic DEA approach for groundwater dam site selection Tameh (A1)

Hoseinabad (A2)

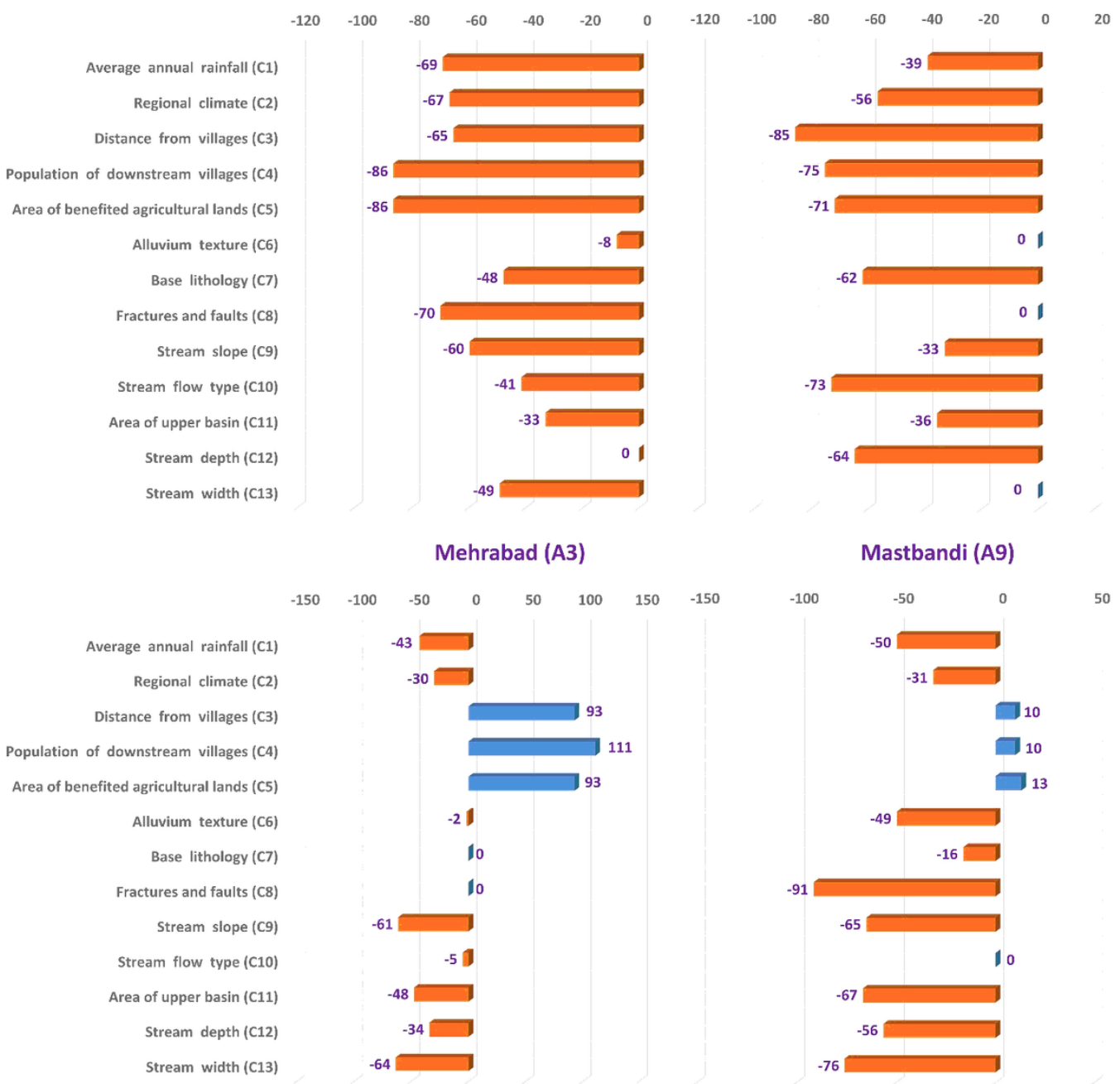


Potential improvement analysis in Socio-Economic DEA approach for four alternatives of groundwater dams

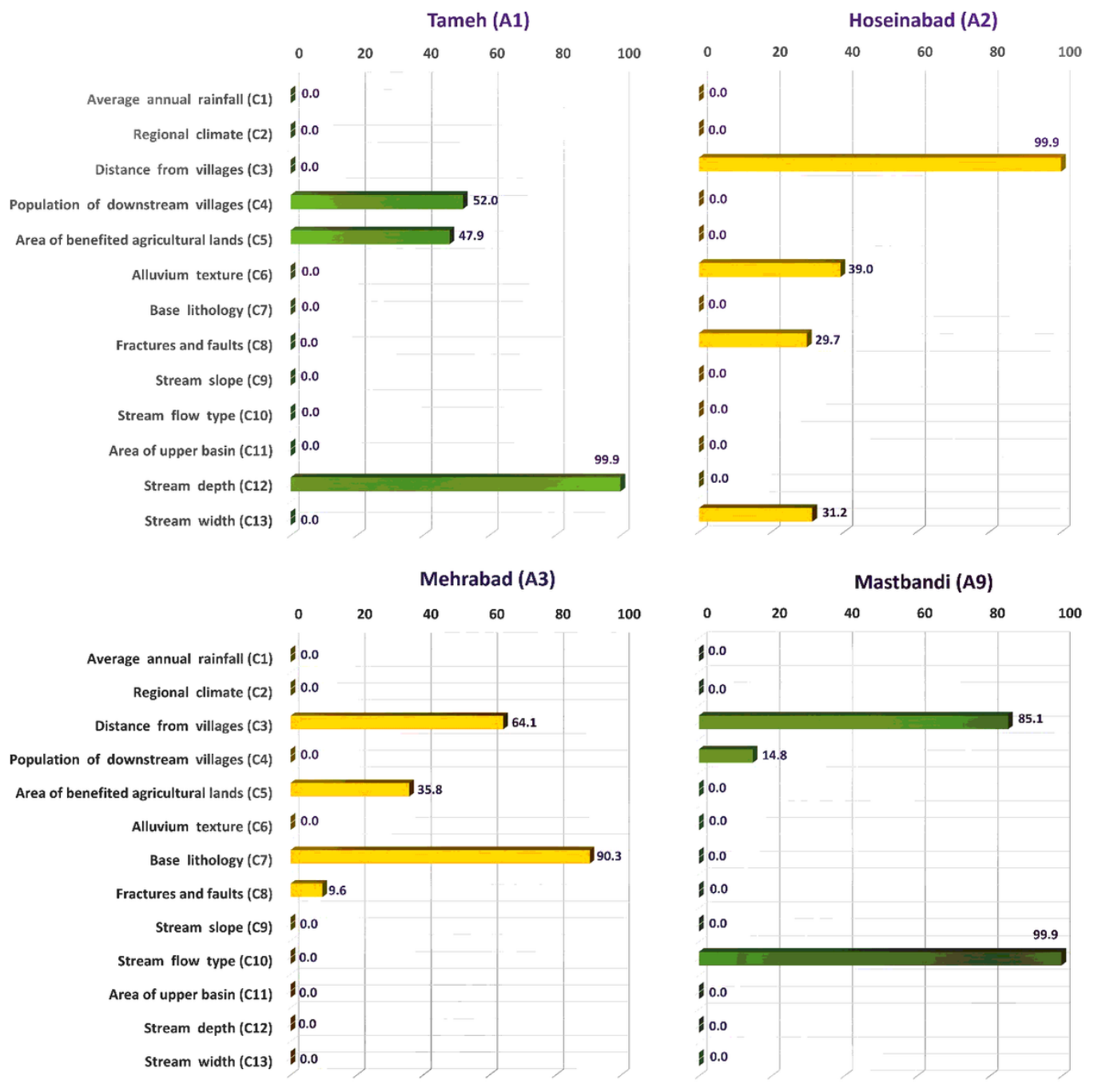

Figure 10

Input/output contribution analysis in Socio-Economic DEA approach for four alternatives of groundwater dams 